\title{
Anterior Cruciate Ligament Reconstruction with Platelet Rich Plasma: Systematic Review
}

\section{Laura FERNANDEZ ${ }^{1}$, Roberto SEIJAS ${ }^{1-3}$, Albert PÉREZ-BELLMUNT ${ }^{1 *}$, Paolo RAGAZZI ${ }^{1}$, Olivier PEILLON and Pedro ALVAREZ ${ }^{1-4}$}

\author{
${ }^{1}$ Anatomy Unit, International University of Catalonia, Spain \\ ${ }^{2}$ Fundación García-Cugat, Spain \\ ${ }^{3}$ GC Arthroscopy, Chiron Hospital, Spain \\ ${ }^{4}$ Catalan Mutualidad de Futbolistas, Spanish Football Federation, Spain
}

* Corresponding author: Albert PÉREZ-BELLMUNT, Assistant Professor of the Area of Structure and Function of the Human Body, Director of Anatomy Laboratories, Faculty of Medicine and Health Sciences, Anatomy Unit, International University of Catalonia, C/Josep Trueta s/n CP 08195, Sant Cugat del Vallès Barcelona, Spain, Tel: +34-935-04-20-14, ORCID: 00000002-5607-0708

\begin{abstract}
Objective: The aim of this study was reviewed the scientific evidence of the relationship that could exist between the use of Platelet Rich Plasma (PRP) after the reconstruction of the Anterior Cruciate Ligament (ACL).

Design: We performed a systematic using the following key words: platelet rich plasma AND anterior cruciate ligament. Abstracts were screened by a single reviewer. For those studies meeting the eligibility criteria, full-text articles were obtained.

Results: From 127 studies found only 5 articles were included in this systematic review. We found the presence of inflammatory diseases, DM, advanced osteoarthrosis (grade III-IV), previous knee surgeries, malignant diseases, contrast allergy, renal disease and thrombocytopenia.

Conclusion: The use of the platelet rich plasma after the $\mathrm{ACL}$ reconstruction with patellar tendon, demonstrates a better autograft recovery in terms of vascularization, bone remodeling and edema decreasing, achieving an earlier autograft homogenization.
\end{abstract}

\section{Keywords}

Anterior cruciate ligament, Platelet rich plasma, Knee, Antlerogenic stem cells, PRP

\section{Introduction}

The Anterior Cruciate Ligament $(A C L)$ is, together with the collaterals medial and lateral ligaments and the posterior cruciate ligament, one of the four main ligaments of the knee [1]. The ACL is the main restraint (impediment) to the anterior displacement of the tibia, it limits the rotation of the tibia and the external and internal angulation of the knee when it reaches its complete extension [2].

The importance of the rupture of the ACL lies in its high incidence, being the ligament with the highest frequency of injury. It has been calculated that 1 every 3000 people a year suffers the rupture of the ACL [3], and the $78 \%$ of these injuries happens during the practice of football, baseball, basketball and skiing [4]. The ACL usually gets injured when the foot gets stuck in the ground and the knee does an internal rotation. In addition to its high incidence, this kind of injury usually gives high articulation instability to the athlete, preventing him from the practice of the sport and causing an important sport-time lost. The treatment of the rupture of the $A C L$ has a vital importance, because avoiding its reconstruction could cause degenerative changes at an early age [5].

One of the current adjuvant therapies is the injection of platelet rich plasma, known as PRP [6]. It is an autologous preparation that contains proteins pro- 
duced by the platelets of our own body, which acts as mediators of the reparation of injured or inflamed tissues. The therapy with growth factors consists in obtaining a greater (It's not known the right amount) number of PRPs starting from the centrifugation of the patient's blood, to be able to inject them in the injured tissue and getting to increase said reparative response. The PRPs are giving a great advance in the medicine's world, because they can be used in a large number of injuries, with a high demand [7]. The main goal of the injection of PRP is to stimulate, promote or initiate the process of healing, regeneration or reparation of the tissue.

In the present study, is reviewed the scientific evidence, through published clinical trials, of the relationship that could exist between the use of PRP after the reconstruction of the $A C L$ and a better recovery of the patellar tendon's autograft (HTH technique). In this way, it is intended to reaffirm the benefits that can be derived from this intervention during the surgery and to give an explanation to the growing demand for this type of therapies.

\section{Hypothesis}

The use of platelet rich plasma after an $\mathrm{ACL}$ reconstruction improves the recovery of the patellar tendon's autograft.

\section{Materials and Methods}

A systematic review of the articles dedicated to investigate the use of platelet rich plasma and its possible beneficial effect in the recovery of the ACL with patellar tendon's autograft has been realized.

Two databases were consulted; Pubmed and Cochrane, using the following key words: platelet rich plasma AND anterior cruciate ligament. By performing the mentioned research, a total of 127 articles were obtained. There were no restrictions in the publication date nor language, taking papers published in Enghlish and in Spanish. The age and gender of the patients and the total population included in the study have not been considered as exclusion criteria neither. Out of 127 articles, 96 were excluded because they weren't clinical trials and after deleting the duplicates, the amount of articles was reduced to a total of 17 . After reviewing the titles and abstracts a total of 12 articles were ignored. The reasons of excluding these clinical trials included being articles investigating the donating place of the graft, articles which used allograft to reconstruct the $\mathrm{ACL}$ or autograft from the hamstring tendon and not making reference to the recovery after the intervention.

After the selection process applying the previously described inclusion and exclusion criteria, a total of 5 articles considered as relevant to the realization of the present study were obtained.

\section{Results}

In this systematic review, 5 studies which include always adult patients were analyzed, being the maximum age of inclusion variable between studies (from 35 to 65 years). All the studies obtained an informed consent by the patients, as well as the approval by a national Ethics Committee. The groups of population in the studies are in all cases comparable in gender, age, body mass index and lesion type.

Within all inclusion and exclusion criteria used in all the studies, we found the presence of inflammatory diseases, DM, advanced osteoarthrosis (grade III-IV), previous knee surgeries, malignant diseases, contrast allergy, renal disease and thrombocytopenia.

In two of the included studies, there was also a platelet re-count of the sample used to get the PRP, obtaining an average of $109 \times 109 / L$ in the PRP group and $207 \times 109 / \mathrm{L}$ in the control group.

The results evaluation and the monitoring and realization of the different controls as the post-surgery time was increasing was made in all the studies with an MRI, using different sequences according to the study outcomes (vascularization, cortical ossification or diffusion coefficient).

\section{Discussion}

The use of PRP is becoming a great advance in the orthopedic and traumatology surgery, entailing an improvement by permitting to achieve advanced stages of bone remodelling at an early stage [8], better vascularization of the graft, less edema [9] and obtaining a homogenous graft in less time after the surgery [10].

Nowadays the use of biological techniques for the treatment of injuries in different types of tissues is on the rise, especially in the field of the application of growth factors riches of platelets obtained through an autologous form (orthopedic, sport medicine, odontology, plastic surgery and maxillofacial surgery) [7]. F. Radis, et al. determined that in the case of reconstruction of the $A C L$, the growth factors derived from platelets, the fibroblastic growth factor type 1 and various types of TGF- $\beta$, are responsible to accelerate the healing process andthe increase in strength and tension of the graft.

In this systematic review, the results of all the included studies are based on a structural analysis using MRI, with no doubts, it is necessary to realize clinical studies that demonstrate the efficiency of the use of PRP to achieve a faster functional recovery for the patients and therefore an early return to his previous sport activity [11].

As it was observed on the study realized by F. Radice, et al. the introduction of a second variable, like the graft used in this case, can modify the benefits that are ob- 
tained from the use of PRP. In this study, according to the sport that the subjects performed, they underwent a reconstruction with patellar ligament using the HTH technique or a reconstruction using the hamstring tendon. It has been observed that in the group of patients that got the PRP after the reconstruction of the ligament, those that received the HTH obtained a homogenization of the graft 68 days earlier than those patients that got the reconstruction done with the hamstring tendon [10]. The fact that the sample number was too small to draw conclusions with statistical significance, it was concluded that it was a type Beta error (mistake), because we could only consider it as a trend. It could suppose a new line of study, observing what type of graft improves or has a synergistic effect with the PRP, would allow to improve the results of the application of this type of biological technique.

M. Vorgin, et al. have demonstrated that the PRP effect is different according to the analyzed zone. As the main objective was to analyze the vascularization ratio, while in the zone between the graft and the bone tun- nels a $p$ value $<0.001$ was obtained at the 4- 6 weeks, in the intra-articular zone the p_value obtained was 0.262 [12]. These results enable the realization and investigation of which factors could be determinant and which differential conditions can be found in the intra-articular zone, responsible of decreasing the PRP effects in contraposition to the zone between the graft and the bone tunnels.

Another interesting fact to consider is the contribution of two of the analyzed studies. M. Vorgin, et al. [12] and M. Rupreht, et al. [9] made a platelet re-count of the patient's blood in both groups. The average obtained was $190 \times 10$ [8] platelet per liter in the PRP group and $207 \times 10$ [8] platelet per liter in the control group. Given that difference in the platelet re-count, being able to influence in the PRP effectiveness, the results showed that there was no influence, neither the relation between the blood platelet level and the PRP effects, as shown in Table 1. Regardless the results, there are no studies to demonstrate with scientific evidence the role of the blood platelet level in modifying the PRP effects.

Table 1: Description of the papers.

\begin{tabular}{|c|c|c|c|c|c|c|}
\hline Authors & Article & Year & $\begin{array}{l}\text { Number of } \\
\text { Subjects }\end{array}$ & Evaluations & P Value & Conclusions \\
\hline $\begin{array}{l}\text { Radice F, } \\
\text { et al. [10] }\end{array}$ & $\begin{array}{l}\text { Comparison of magnetic } \\
\text { resonance imaging } \\
\text { findings in anterior } \\
\text { cruciate ligament } \\
\text { grafts with and without } \\
\text { outologous platelet- } \\
\text { derived growth factors }\end{array}$ & 2010 & $\begin{array}{l}50 \text { subjects } \\
\text { Age from } 18 \\
\text { to } 35 \mathrm{y} / \mathrm{o}\end{array}$ & $\begin{array}{l}\text { Continuous } \\
\text { controls until the } \\
\text { obtaining of a } \\
\text { homogeneous } \\
\text { graft }\end{array}$ & $\begin{array}{l}\text { Reduction } \\
\text { of the time } \\
\text { between PRP } \\
\text { group and } \\
\text { control group } \\
\text { of } 48 \% \text { with } p< \\
0.001\end{array}$ & $\begin{array}{l}\text { The use of PRP in the } \\
\text { ACL reconstruction } \\
\text { gets homogeneous and } \\
\text { completed grafts evaluated } \\
\text { by MRI at the time of } 179 \\
\text { days, in comparison with } \\
\text { the time of } 369 \text { days on } \\
\text { those reconstructed without } \\
\text { PRP. This time reduction } \\
\text { represents a } 48 \% \text {. } \\
\text { Regarding to the } \\
\text { reconstruction with the } \\
\text { HTH technique and } \\
\text { patellar tendon, } 109 \text { days } \\
\text { are required to obtain an } \\
\text { homogeneous graft in } \\
\text { those patients with PRP, } \\
\text { compared to } 363 \text { days in } \\
\text { the control group. }\end{array}$ \\
\hline $\begin{array}{l}\text { Vogrin M, } \\
\text { et al. [12] }\end{array}$ & $\begin{array}{l}\text { Effects of a platelet } \\
\text { gel on early graft } \\
\text { revascularization after } \\
\text { anterior cruciate ligament } \\
\text { reconstruction: a } \\
\text { prospective, randomized, } \\
\text { double blind, clinical trial }\end{array}$ & 2010 & $\begin{array}{l}50 \text { subjects } \\
\text { Age from } 18 \\
\text { to } 50 \mathrm{y} / \mathrm{o}\end{array}$ & $\begin{array}{l}\text { 4-6 weeks } \\
\text { (interzone) } \\
\text { 10-12 weeks } \\
\text { (interzone) } \\
\text { 4-6 weeks (intra- } \\
\text { articular) } \\
\text { 10-12 weeks } \\
\text { (intra-articular) }\end{array}$ & $\begin{array}{l}P<0.001 \\
P=0.404 \\
P=0.262 \\
P=0.404\end{array}$ & $\begin{array}{l}\text { The platetet-rich plasma, } \\
\text { locally applied, has } \\
\text { demonstrated an earlier } \\
\text { graft's revascularization } \\
\text { in the interzone between } \\
\text { the bone and the ligament, } \\
\text { without obtaining a } \\
\text { statistically significant } \\
\text { difference in the intra- } \\
\text { articular zone. }\end{array}$ \\
\hline $\begin{array}{l}\text { Seijas R, } \\
\text { et al. [8] }\end{array}$ & $\begin{array}{l}\text { Magnetic resonance } \\
\text { imaging evaluation of } \\
\text { patellar tendon graft } \\
\text { remodelling after anterior } \\
\text { cruciate ligament } \\
\text { reconstruction with or } \\
\text { without platelet-rich- } \\
\text { plasma }\end{array}$ & 2013 & $\begin{array}{l}98 \text { subjects } \\
\text { Age from } 18 \\
\text { to } 65 \mathrm{y} / \mathrm{o}\end{array}$ & $\begin{array}{l}4 \text { months } \\
6 \text { months } \\
12 \text { months }\end{array}$ & $\begin{array}{l}P=0.003 \\
P=0.0001 \\
P=0.354\end{array}$ & $\begin{array}{l}\text { The PRP allows achieving } \\
\text { advanced stations of } \\
\text { the graft's remodeling } \\
\text { in different phases, in } \\
\text { comparison with the control } \\
\text { group. }\end{array}$ \\
\hline
\end{tabular}




\begin{tabular}{|c|c|c|c|c|c|c|}
\hline $\begin{array}{l}\text { Rupreht } \\
\text { M, et al. } \\
\text { [9] }\end{array}$ & $\begin{array}{l}\text { Evaluation of the } \\
\text { tibial tunnel after } \\
\text { intraoperatively } \\
\text { administred platelet- } \\
\text { rich plasma gel during } \\
\text { anterior cruciate ligament } \\
\text { reconstruction using } \\
\text { diffusion weighted and } \\
\text { dynamic contrasc- } \\
\text { enhanced MRI }\end{array}$ & 2013 & $\begin{array}{l}50 \text { subjects } \\
\text { Age from } 18 \\
\text { to } 50 \mathrm{y} / \mathrm{o}\end{array}$ & $\begin{array}{l}1 \text { month } \\
2.5 \text { months } \\
6 \text { months }\end{array}$ & $\begin{array}{l}\text { ADC } p=\mathbf{0 . 0 3 3} \\
\text { Genh } p=0.019 \\
\text { Fenh } p=0.100 \\
\text { ADC } p=\mathbf{0 . 4 1 9} \\
\text { Genh } p=0.008 \\
\text { Fenh } p=0.068 \\
\text { ADC } p=109 \\
\text { Genh } p=0.531 \\
\text { Fenh } p=0.419\end{array}$ & $\begin{array}{l}\text { In both types of MRI used, } \\
\text { there was a minor edema } \\
\text { (ADC) during the first } \\
\text { month after surgery, as well } \\
\text { as an increased vascular } \\
\text { density and microvessels } \\
\text { permeability (Genh and } \\
\text { Fenh) in the tibial proximal } \\
\text { tunnel at the periods } \\
\text { of } 1 \text { and } 2.5 \text { months as } \\
\text { an effect of the PRP } \\
\text { application. }\end{array}$ \\
\hline $\begin{array}{l}\text { Rupreht } \\
\text { M, et al. } \\
\text { [9] }\end{array}$ & $\begin{array}{l}\text { MRI evaluation of tibial } \\
\text { tunnel wall cortical bone } \\
\text { formation after platelet- } \\
\text { rich plasma applied } \\
\text { during anterior cruciate } \\
\text { ligament construction }\end{array}$ & 2013 & $\begin{array}{l}50 \text { subjects } \\
\text { Age from } 18 \\
\text { to } 50 \mathrm{y} / \mathrm{o}\end{array}$ & $\begin{array}{l}1 \text { month } \\
2.5 \text { months } \\
6 \text { months }\end{array}$ & $\begin{array}{l}P=0.928 \\
P=0.004 \\
P=0.003\end{array}$ & $\begin{array}{l}\text { The local application of } \\
\text { platelet-rich-plasma has } \\
\text { demonstrated to enhance } \\
\text { the cortical bone formation } \\
\text { surrounding the tibial } \\
\text { tunnel after the ACL } \\
\text { reconstruction. }\end{array}$ \\
\hline
\end{tabular}

\section{Conclusion}

The use of the platelet-rich plasma after the ACL reconstruction with patellar tendon, seems to demonstrate a better autograft recovery in terms of vascularization, bone remodeling and edema decreasing, achieving an earlier autograft homogenization.

This improvement could reduce the rehabilitation time after the surgery, allowing the patient to get earlier to his sport practice. Due to the fact that studies carried out since now are focusing on graft's anatomical and structural recovery, it's recommended to conduct studies that demonstrate that the beneficial effects identified in this systematic review allow an earlier restoration in a functional scope to make conclusions about the impact on the quality of life recovery previous to the ACL rupture.

\section{Declaration of Interests}

No potential conflict of interest was reported by the authors.

\section{References}

1. Vaquero J, Haro JAC, Campos FF (2008) Reconstrucción del ligamento cruzado anterior. Trauma 19: 22-38.

2. Forriol F, Maestro A, Vaquero J (2008) El ligamento cruzado anterior: morfología y función. Trauma Fund MAPFRE 19: 7-18.

3. Mejías JDA, García-Estrada GA, Pérez-España LA (2015) Actualización en las Lesiones del Ligamento Cruzado Anterior. Análisis de los Resultados Mediante TAC y Escalas Clínicas 22: 1-11.

4. D’Elía MC (2015) Prevalencia de Lesiones Asociadas a Rotura Aguda de Ligamento Cruzado Anterior (LCA)-Asociación Argentina de Traumatología del Deporte. Revista de la Asociación Argentina de Traumatología del Deporte 22.

5. Papathanasiou I, Michalitsis S, Hantes ME, Vlychou M, Anastasopoulou L, et al. (2016) Molecular changes indicative of cartilage degeneration and osteoarthritis development in patients with anterior cruciate ligament injury. BMC musculoskelet Disord 17: 21.

6. Bos-Mikich A, de Oliveira R, Frantz N (2018) Platelet-rich plasma therapy and reproductive medicine. J Assist Reprod Genet 35: 753-756.

7. Wang-Saegusa A, Cugat R, Ares O, Seijas R, Cuscó X, et al. (2011) Infiltration of plasma rich in growth factors for osteoarthritis of the knee short-term effects on function and quality of life. Arch Orthop Trauma Surg 131: 311-317.

8. Seijas R, Ares O, Catala J, Alvarez-Diaz P, Cusco X, et al. (2013) Magnetic resonance imaging evaluation of patellar tendon graft remodelling after anterior cruciate ligament reconstruction with or without platelet-rich plasma. J Orthop Surg 21: 10-14.

9. Rupreht M, Jevtič V, Serša I, Vogrin M, Jevšek M (2013) Evaluation of the tibial tunnel after intraoperatively administered platelet-rich plasma gel during anterior cruciate ligament reconstruction using diffusion weighted and dynamic contrast-enhanced MRI. J Magn Reson Imaging 37: 928935.

10. Radice F, Yánez R, Gutiérrez V, Rosales J, Pinedo M, et al. (2010) Comparison of magnetic resonance imaging findings in anterior cruciate ligament grafts with and without autologous platelet-derived growth factors. Arthroscopy 26 : 50-57.

11. Figueroa PD, Figueroa BF, Ahumada PX, Calvo RR, Vaisman BA (2013) [Use of platelet rich plasma in knee ligament surgery]. Rev Med Chil 141: 1315-1320.

12. Vogrin M, Rupreht M, Dinevski D, Haspl M, Kuhta M, et al. (2010) Effects of a platelet gel on early graft revascularization after anterior cruciate ligament reconstruction: a prospective, randomized, double-blind, clinical trial. Eur Surg Res 45: 77-85. 